\title{
Using eLearning To Build Workforce Capacity Among Business Professionals
}

Paul J. Carruth, Southeastern Louisiana University, USA

Ann K. Carruth, Southeastern Louisiana University, USA

\begin{abstract}
In the current evolving economic environment, developing and implementing effective processes to improve the skills and capability of employees are seen as central to improving individual, organizational and national performance and global competitiveness. Recognizing that universities and colleges are critical to their state's growth and economic prosperity, many governors and state policymakers have been considering how best to get more students to both enter college and get college degrees. A growing number of policymakers have come to recognize that higher education, including community colleges, four-year colleges, and research universities, cannot help drive economic growth in their states unless students' academic success is linked to the needs of the marketplace. For example, to address this need, the Louisiana GRAD Act (HB1171) was recently enacted to support the state's post-secondary education institutions in increasing their overall effectiveness. Institutions develop specific measurable performance objectives aimed at improving college completion and meeting the state's current and future workforce and economic development. One of the Act's student success indicators cites, "Increase the use of technology for distance learning to expand educational offerings." At all levels of education, online learning is one of the fastest growing trends in educational uses of technology (www.ed.gov). It is now commonly agreed on that educational benchmarks and expectations can be achieved equally well, and in some cases better, than with traditional face-to-face courses (www.ed.gov). Many faculty choose to combine multiple forms of synchronous and asynchronous online interactions. A successful eLearning experience will use a combination of the technologies most appropriate for the practitioner, the learner group, the course content, and course assessment.
\end{abstract}

Keywords: Workforce Development; eLearning; Business

\section{INTRODUCTION}

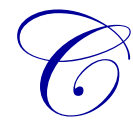

hanges in our economy have resulted in new sources of wealth, changing patterns of international trade, and a shift in the balance between capital and labor. These changes have been driven by both technological innovation and globalization, resulting in a profound restructuring of the U.S. workplace (Kirsch Braun \& Yamamoto, 2007). In fact, the labor markets of today are markedly different from those of earlier decades. In 1950, manufacturing's share of total employment in the United States was 33.1 percent. By 1989, it was down to 18.2 percent and by 2003, it was 10.7 percent. Between 1984 and 2000, the number of employed persons 16 years of age and older grew by 29 percent (30 million). At the same time, employment in jobs associated with college level education grew by some 20 million, accounting for two-thirds of the job growth. The country's employment growth is expected to continue through the rest of this decade and into the next, with college labor market clusters (professional, management, technical, and high level sales) expected to generate about half of all job growth. Unlike previous generations, all economic indicators suggest that post-secondary education will be essential to secure middle class status. Technology is a skill that transcends all middle and high skill level occupations. This paper will explore the factors central to online education and the possible impact and transferability of needed technology to the business work environment. 


\section{THE FORECAST FOR WORKFORCE NEEDS}

One important consequence of the shift in the composition of jobs in our country has been the increasing economic returns for those workers with education and skills. For example:

- $\quad$ The expected lifetime earnings of males with a bachelor's degree in 1979 were 51 percent higher than their peers with only a high school diploma. By 2004, however, this difference had widened to 96 percent.

- $\quad$ The earnings premiums accruing to a particular level of educational attainment (e.g., high school diploma, bachelor's degree) are substantially larger for individuals at that level who have higher cognitive skills, indicating that both education and skills contribute to individual opportunities. Not only are these jobs higher paying, they are also more likely to provide opportunities for workers to take advantage of employer sponsored training to enhance and broaden their skills throughout their careers.

The very nature of work in the United States is under extreme competitive pressure to adapt. Technological changes, particularly information technologies, has had and will continue to have a substantial impact on the structure of jobs and the demand for certain skill sets in the U.S. labor market (Kirsch, Braun \& Yamamoto, 2007).

\section{TRENDS IN ECONOMIC OUTLOOK, EDUCATIONAL PREPARATION AND OCCUPATIONS}

Based on Bureau of Labor Statistics (BLS) estimates of educational attainment and training of various industries, occupational groups can be divided into high-skill, middle-skill, and low-skill categories. Using this information, Holzer and Lerman (2009) define high-skill occupations as those in the professional/technical and managerial categories. Middle-skill occupations include clerical, sales, construction, installation/repair, production, and transportation/material moving. Low-skill occupations are those in the service and agricultural categories. Data support that over the last two decades, jobs have expanded faster in both high-skill and low-skill positions than in middle-skill positions (Holzer \& Lerman, 2009).

Both middle and high-skill positions require educational preparation at some level. Currently, nearly half of all jobs are in middle-skilll occupations, which require more than a high school diploma but less than a four-year college degree. In many cases, these jobs pay well. However, even though these jobs are expected to remain in high demand across the U.S. labor market, too few workers now have the skills to fill them. It is estimated that between 2008 and 2018, of the nearly 47 million anticipated middle-skilll job openings, 63 percent will require at least some college education and strong basic skills in math, science, and other technical areas.

Over the 1990s, gains in jobs and wages rose more rapidly at the top and bottom of the earnings distribution than in the middle, in part because computers more easily replace jobs in the middle of the market than at the top or the bottom. The jobs at the top require abstract reasoning and those at the bottom are more important than computers. David Autor of MIT and others have warned of a growing "polarization" between workers with high and low earnings, conveying popular images of a "dumbbell" labor market, or an "hourglass economy." (Holzer \& Lerman, 2009). Businesses continue to require high-skill positions. These include management and financial operations. The broad category requiring high-skills, professional and related occupations, rose from 17 percent in 1986 to more than 20 percent in 2006 and managerial positions increased from about 12 to 15 percent of total employment. This trend is expected to continue. Educational institutions will likely be called on to design curricula to meet the shift in skills requiring informational technology, to keep pace with the needs of businesses looking to employ graduates in high-skill positions.

The idea of an hourglass economy has been supported by the fact that weekly earnings gap between workers with college degrees versus workers with high school diplomas has certainly widened for over 30 years. The exception has been between 2000 and 2006 for full-time workers above age 24 where no increase was noted during that time. Those with associate degrees now earn, per year of education, a similar wage premium over those with only a high school diploma. In 2006, the median worker with an associate degree earned about 33 percent more than those with only a high school degree, while those with a BA degree and no graduate degree earned 62 percent more (Holzer \& Lerman, 2009). 

show that:

Specifically, Carnevale, Smith, \& Strohl (2010) provide analysis of occupations and wage earnings. Data

- The range in lifetime earnings by educational attainment is greatest between high school dropouts and professional degrees - a range of $\$ 1,198,000$ to $\$ 4,650,000$ or a difference of $\$ 3,452,000$.

- $\quad$ A high school degree is worth about $\$ 569,000$ more than being a dropout.

- Having some college but no degree or a post-secondary certificate is worth about $\$ 473,000$ more than a high school degree.

- $\quad$ An Associate's degree is worth about \$15,000 more than some college but no degree.

- A Bachelor's degree is worth about $\$ 1.1$ million more than an Associate's degree.

- $\quad$ A Master's degree is worth $\$ 457,000$ more than a Bachelor's degree.

The BLS Occupational Outlook Handbook, 2010-11 edition, describes employment projections. Industry growth or decline will affect demand for occupations. However, job growth is projected to vary among major occupational groups. Professional and related occupations, which includes a wide variety of skilled professions, is expected to be the fastest growing major occupational group, at 17 percent, and is projected to add the most new jobs-about 5.2 million. Management, business, and financial occupations is the fourth fasting growing major occupational group at 11 percent. . Workers in management, business, and financial occupations plan and direct the activities of business, government, and other organizations. Their employment is expected to increase by 11 percent by 2018. These workers will be needed to help organizations navigate the increasingly complex and competitive business environment. A large portion of these jobs will arise in the management, scientific, and technical consulting industry sector. A substantial number of jobs are expected in several other large or rapidly growing industries, including government, healthcare and social assistance, finance and insurance, and construction.

Employment in management occupations is projected to grow slowly over the projection period, increasing by 5 percent, an addition of 454,300 new jobs. Growth is being affected by declines in several occupations, including farmers and ranchers. Employment of farmers and ranchers is projected to decline as the agricultural industry produces more output with fewer workers (http://www.bls.gov/oco/oco2003.htm).

Employment in business and financial operations occupations is projected to grow by 18 percent, resulting in 1.2 million new jobs. Increasing financial regulations and the need for greater accountability will drive demand for accountants and auditors, adding roughly 279,400 jobs to this occupation from 2008 to 2018. Further, an increasingly competitive business environment will grow demand for management analysts, an occupation that is expected to add 178,300 jobs. Together, these two occupations are anticipated to account for 38 percent of new business and financial operations jobs (http://www.bls.gov/oco/oco2003.htm).

Those occupations on the decline are tied to lower levels of post-secondary education. Declining occupational employment stems from falling industry employment, technological advances, changes in business practices, and other factors. For example, technological developments and the continued movement of textile production abroad are expected to contribute to a decline of 71,500 sewing machine operators over the projection period (table 3). Fifteen of the 20 occupations with the largest numerical decreases are either production occupations or office and administrative support occupations, both of which are adversely affected by increasing plant and factory automation or the implementation of office technology, reducing the need for workers in those occupations. http://www.bls.gov/oco/oco2003.htm).

Monthly Labor Review marks the release of the 2008-18 employment projections of the Bureau of Labor Statistics (BLS) include two projections likely to impact the student enrollment in post-secondary institutions (Bartsch, 2009). Interestingly, one supports increase in enrollment in post-secondary institutions and one does not.

- The professional and business services sector and the health care and social assistance sector are anticipated to grow at more than twice the annual average of 1.0 percent for all industries, adding the most employment, 4.2 million and 4.0 million, respectively. 
- Nearly two-thirds of the 30 occupations with the largest expected numerical increase have short-, moderateor long-term on-the-job training as their most significant source of education or training.

More recently, with the advent of substantial amounts of worldwide broadband capacity, outsourcing not only of manufacturing jobs but also of so-called knowledge worker jobs is becoming increasingly common. It is estimated that 14 million or 11 percent of total employment could be "off-shored" to other countries. This is possible due to the increasing reliance on informational technology (Garner, 2004).

Many types of service-sector work is being sent overseas. For example, call centers and help desks to software development, income tax form preparation, financial research, engineering and architectural design, and medical diagnosis, have all been off-shored. This trend has been found to be both feasible and economically beneficial because work is being performed where wages and the cost of benefits are much lower than in the United States. However, it is cautioned that just because a job can be done elsewhere, does not mean it will be.

The Employment Projections Program (EPP) develops information about the labor market for the Nation as a whole for 10 years in the future. Occupations assigned to the post-secondary degree categories are expected to grow faster than the on-the-job and work experience category occupations. Among the categories, the fastest growth will occur in occupations whose most significant source of education is an associate degree, while the slowest growth will be among occupations in the on-the-job training categories. Nonetheless, occupations in the short- and moderate-term on-the-job training categories made up the largest share of employment in 2008, and are projected to continue to hold the largest share of employment in 2018. Occupations categorized in post-secondary categories are projected to have the fastest growth from 2008-18. In spite of this rapid growth, occupations in the on-the-job training and work experience categories still are projected to comprise the majority share of 2018 employment. In addition, median annual wages of occupations categorized as post-secondary on average have higher wages than occupations in on-the-job training categories. (http://www.bls.gov/emp/ep_education_training.htm).

By 2018, it is estimated that the United States will come up at least 3 million post-secondary degrees short of employers' demands. Human resources executives indicate very high talent shortages in the United States in technology, trade, financial services, real estate, health care, and education by 2030 (Carnevale, Smith, \& Strohl, 2010).

\section{EVALUATING SKILLS FOR THE $21^{\text {ST }}$ CENTURY WORKFORCE}

The ability of individuals to connect education, workforce training, and occupations has become key to employability and to attaining and maintaining middle class status (Carnevale, Smith, \& Strohl, 2010). Changes in the occupational structure in the United States have important consequences for the post-secondary educational and literacy requirements of jobholders. The demand for college-educated and more highly literate workers has increased over the past two decades, enhancing the economic benefit of seeking education and skills. In addition to educational attainment, literacy and numeracy proficiencies of U.S. adults have a strong influence on their ability to gain access to the more highly skilled professional management, and technical occupations. Job categories that require higher level literacy also support employers providing opportunities to participate in employer sponsored training.

When the 1992 National Adult Literacy Survey was conducted, it was found that completed years of postsecondary education was closely associated with their prose and quantitative proficiency scores. Among both associate degree and bachelor's degree recipients, the likelihood of employees holding a college labor market job was strongly and consistently correlated with their prose and quantitative proficiencies. Interestingly, college graduates with weak literacy and numeracy proficiencies were much more likely than their more highly skilled peers to be underemployed. They were more likely to hold jobs that did not require a college degree and paid considerably less than their more highly skilled counterparts (Kirsch, Jungeblut, Jenkins, and Kolstad, 2003).

The Adult Literacy and Life Skills (2003) survey is an international comparative designed to provide participating countries, including the United States, with information about the skills of their adult populations. ALLS measured the literacy and numeracy skills of a nationally representative sample from each participating 
country and found that U.S. workers with strong skill profiles were much more likely to have jobs that required them to engage in reading and writing tasks at work (http://nces.ed.gov/surveys/all/). In both literacy and numeracy among 16 to 65 year olds by country, United States placed 5th. Norway, Bermuda, Switzerland and Canada scored significantly higher than the U.S. average. Only Italian citizens scored significantly lower (http://nces.ed.gov/pubs2005/2005117.pdf). To keep pace with globalization, post-secondary education needs to increase opportunities for improved literacy and numeracy levels.

\section{PARADIGM SHIFT IN POST-SECONDARY RESPONSIBILITY}

Most policy makers and university administrators focus their attention on student access, student achievement, and degree completion. However, a new emphasis is being placed on not only getting more Americans through the educational system to graduation, but to also get these same adults ready for jobs to meet the future needs of the U.S. economy. The NGA recommends that the success of graduates will require universities and colleges to strategically match degree programs, knowledge and research skills to an economy that focuses on innovation and revitalization of key industry clusters (NGA, 2011). These initiatives will address the concerns that higher education is fragmented and not addressing the knowledge-based job market.

Recognizing that universities and colleges are critical to their state's growth and economic prosperity, many governors and state policymakers have been considering how best to get more students to both enter college and get college degrees. In fact, many of the nation's governors are participating in the National Governors Association (NGA), 2010-2011 Chair's initiative, Complete to Compete, which focuses on helping states improve their students' college graduation rates. However, it has become imperative that students' academic success needs to be linked to the needs of the marketplace. Through leadership, policy directives, and legislative funding, higher education institutions are beginning to embrace the initiative to prepare a new workforce to meet the needs of jobs of a new economy. To this end, states have established comprehensive goals to align educational preparation and outcomes with state's economic needs.

The skills that workers must have to thrive in the 21 st century economy are different from the skills that workers had to have in the past. To participate in the 21 st century knowledge-based economy, students must increasingly be comfortable with critical thinking and problem solving, communication, collaboration, creativity, and innovation. Many states, including Minnesota, Washington, and Ohio, have established college or universitybased centers of excellence in particular industry sectors important to the state or regional economy. These centers are often established at flagship research universities to strengthen state and local capabilities for innovation. They are also expected to obtain input from employers on their workforce needs, develop new curricula to meet these needs, and provide education and training to prepare students for job openings in the industry. Washington's 11 centers of excellence were originally housed at two-year institutions of higher education to serve regional industry needs. However, they have evolved to serve as statewide industry sector leaders, overseeing services and programming affecting their sector for the system's 34 colleges. These centers help employers and citizens in Washington find education and training opportunities in their local areas or arrange distance-learning opportunities.

Using visits to employers and quantitative labor market information, the Minnesota system is developing a plan to do the following:

- $\quad$ Strengthen courses and programs so that students learn the emerging skills employers have identified:

- $\quad$ Expand opportunities for internships and apprenticeships

- $\quad$ Strengthen relationships with local businesses through outreach, communications, and collaborations

- $\quad$ Expand educational offerings to include more online education, experienced-based learning, and flexible options (Sparks, \& Waits, 2011)

As a result of discussions surrounding alignment between post-secondary education and occupational and workforce needs, at least 14 states have performance-based funding for their institutions of higher learning. A few states have refined their performance-based funding systems to incorporate measures of the alignment of higher education with the state's economic priorities. Some states have developed competitive programs that provide additional competitive funding to post-secondary institutions for proposing and engaging in specific alignment 
activities. Increasingly, incentives to connect to industry are included in formula funding and competitive grants, as well as student financial aid (Dougherty \& Natow, 2009).

Minnesota's higher education system is eligible to receive 1 percent of its appropriation only after it has achieved at least three of five goals aligned with state economic priorities. One of these goals is to increase the number of students taking online courses or the number of online courses offered by at least 10 percent, compared to fiscal 2007. In Louisiana, Granting Resources and Autonomy for Diplomas (GRAD) Act (HB 1171) was recently enacted to support the state's post-secondary education institutions in increasing overall effectiveness. Institutions develop specific measurable performance objectives aimed at improving college completion and meeting the state's current and future workforce needs. One of the Act's success indicators requires an increase in the number of distance education courses offered by universities.

\section{eLEARNING TRENDS}

Electronic online learning, or eLearning, is defined as learning that takes place partially or entirely over the Internet. Typically these courses are web-based or offered through a software program called Learning Management Systems (LMS). Evolving eLearning technologies have made asynchronous instruction appealing and have increased interest among academic and healthcare communities. While traditional, synchronous instruction typically takes place in a classroom with instructors delivering lectures, in an asynchronous format the courses provide for a more student-centered and project-based learning environment. A blended or hybrid approach involves a combination of traditional classroom instruction and eLearning.

It is now commonly agreed on that educational benchmarks and expectations can be achieved equally well, and in some cases better, than with traditional face-to-face courses (Kenny, 2002; Means, et al, 2009; www.ed.gov). eLearning is self-paced and the learning sessions are available 24/7. Learners are not bound to a specific day/time to physically attend classes. They can also pause learning sessions at their convenience. Modern online learning includes offerings that run the gamut from conventional didactic lectures or textbook-like information delivered over the Web to Internet-based collaborative role-playing in social simulations and highly interactive multiplayer strategy games.

The demand for online courses is increasing at all levels of the curriculum in high schools and higher education. As we continue to meet the needs of our new students, teaching to generational differences and understanding these life experiences is imperative. The level of prerequisite technological competencies needed to participate in eLearning among prospective students varies greatly. For the majority of freshman students, enrolling in an online course is the first time they experience eLearning, especially since these skills were not needed for faceto-face classroom instruction as high-school students. However, at all levels of education, online learning is one of the fastest growing trends in educational uses of technology (Means et.al, 2009; www.ed.gov). Different technology applications are used to support different models of online learning. For example, asynchronous communication tools (e.g., e-mail, threaded discussion boards, newsgroups) allow users to contribute to communication at students' convenience. Synchronous technologies (e.g., webcasting, chat rooms, desktop audio/video technology) are used to approximate face-to-face (f2f) teaching strategies such as delivering lectures and holding meetings with groups of students. Many faculty choose to combine multiple forms of synchronous and asynchronous online interactions.

The gap between desire to learn and technological competence may be related to the generational group they belong. Adult learners "rely on their kids to help with getting the technology". The YouTube video "Closing the Learning Gap" illustrates the power of eLearning. More importantly, it illustrates that students with technological deficiencies are at a disadvantage when starting an online educational program.

In a national report outlining the critical issues in higher education, Reauthorizing the Higher Education Act: Issues and Options points out that many students with the ability to benefit from an advanced degree do not receive the academic support they need to complete their higher education program (Wolanin, 2003). Although distance education has many advantages, there are many barriers that students must overcome to achieve a successful outcome. Poor or inefficient technological skills can cause frustration, resulting in a decrease in motivation for students. Proficiency in word processing programs, such as Microsoft Office, and basic computer 
knowledge is necessary for online education. Also, learning how to utilize web-based Learning Management Systems, such as Blackboard and Moodle, are needed to complete coursework. Technologically challenged students enrolled in online programs must have a clear understanding of course delivery, be able to access resources from remote locations, and participate in asynchronous course activities to successfully complete an online course (Bower, 2001).

Traditional classroom settings provide for face to face instructor-student and student-student interaction. Online education eliminates the opportunity for $\mathrm{f}_{2} \mathrm{f}$ interaction but does not necessarily inhibit quality interactions. In order to succeed in an eLearning educational program, students must maintain a high degree of dedication and motivation to avoid barriers becoming insurmountable challenges. In order to avoid these pitfalls, institutions are expected to provide assistance and training for technological needs for students and instructors throughout the semester (Bower, 2001). One way to communicate a level of institutional commitment is to provide training in skills needed to not only navigate learning management systems but also skills needed to navigate the institutional resources available (i.e online writing centers and technology help desks).

To address the growing need for educational opportunities, Massachusetts Institute of Technology (Lewin, 2011) has announced a new program allowing anyone to take MIT courses online free of charge and earn official certificates for demonstrating mastery of knowledge-based content areas. Certificates are used in the workforce to demonstrate a highly selective skill set. For those universities that prescribe to Prior Learning Assessments, these certificates and the experiential learning experiences can be used to develop portfolios that eventually lead to college credit. Having credible online certification programs helps promote online education and adult learning at the same time.

With so many high schools looking to address career pathways, post-secondary education needs to consider collaborating with principals and teachers to make sure that students are engaged in pathway skills that will prepare them for university life. Career pathways not only teach core academic subjects such as English, science, mathematics, but also those subjects such as business technologies or health sciences. Increasingly more high schools use online technologies. Enrollment in career pathways and post-secondary education that advance acquisition of high level skills is essential to meet future workforce needs.

Online education is the most efficient way for people with jobs and families to learn new skills, earn certifications, and obtain bachelors and masters degrees. In many states, offices of workforce development leverage online courses to train the workforce. Professional development programs that address local business needs is another example of how online education can be used to develop an educated workforce. In all of these cases, workers gains skills to remain competitive in a technology intensive work environment. Metrejean \& Noland (2011) surveyed CPA firm recruiters on whether online rather than brick and mortar Master of Accounting degree was a factor in the hiring decision. Results show that recruiters do not perceive any differences in delivery format. Research to examine employers perceptions of literacy, numeracy, and computer skills among graduates who enroll in online versus traditional classroom-based accounting programs is needed.

\section{eLEARNING AND MEETING WORKFORCE NEEDS}

The push to keep businesses competitive and profitable will increase demand for services involving professional and business training. Management, scientific, and technical consulting services will be in great demand. In addition, computer systems design and related services will be needed to develop and implement new technologies, provide computer security, and maintain computer networks (Bartsch, 2009). Occupations, like industries, are categorized into groups for analysis and reporting purposes. BLS occupational projections data are categorized into 10 groups based on the Standard Occupational Classification Manual.

It has been determined that professional and related occupations and service occupations together are expected to add 9.3 million of the 15.3 million new jobs created throughout the economy during the next 10 years. Network systems and data communications analysts and computer software engineers are projected to be among the top 10 fastest growing industries. At the opposite end of the employment spectrum are farming, fishing, forestry, and production occupations, which are expected to lose jobs by 2018 (Lacey \& Wright 2009). Many occupations 
with average or slower-than-average growth still will contribute a good number of business-related jobs because of their employment size such as retail salespersons, bookkeeping, accounting, and auditing. Employment in business and financial operations occupations is projected to grow by 17.7 percent, resulting in 1.2 million new jobs.

Increasing financial regulations and the need for greater accountability will drive demand for accountants and auditors, an occupation that is expected to add roughly 279,400 jobs from 2008 to 2018 . In addition, an increasingly competitive business environment will result in greater demand for management analysts, an occupation that is anticipated to add 178,300 jobs. It estimated that, together, these two occupations will account for almost 4 in 10 new business and financial operations jobs.

Employment in management occupations, however, is projected to grow more slowly, increasing by 5.1 percent, or 454,300 new jobs. Service-providing sectors will expand their employment, growing from 77.2 percent of total employment in 2008 to an anticipated 78.8 percent in 2018 (Lacey \& Wright 2009). Strong growth of professional and business services, educational services, and health care and social assistance influences these upward trends.

Many of these occupations require high levels of education or training (Lacey \& Wright 2009). In 2008, about 3 in 10 jobs were in occupations that were classified in a category involving some form of post-secondary award or degree. It is projected that occupations in such categories will account for almost half of all new jobs created from 2008 to 2018. For the 30 the occupations that are expected to decline in numbers, 29 require substantial on-the-job training. In contrast, many of the business-related occupations require post-secondary education, and it is estimated that high skill level-using computers will be required.

By 2018, the economy will create 46.8 million openings, 13.8 million brand-new jobs and 33 million "replacement jobs," positions vacated by workers who have retired or permanently left their occupations. Nearly twothirds of these jobs - some 63 percent - will require workers with at least some college education. About 33 percent will require a Bachelor's degree or better, while 30 percent will require some college or a two-year Associate's degree. Only 36 percent will require workers with just a high school diploma or less (Carnavale, Smith, \& Strohl, 2010). In essence, occupations as a whole are steadily requiring more education. Essentially, post-secondary education or training has become the threshold requirement for access to middle-class status and earnings in good times and in bad. It is no longer the preferred pathway to middle-class jobs - it is, increasingly, the only pathway. In addition, education and training must be made available to non-traditional students outside the typical age group for college. This is considered critical to serving workers whose jobs from last the decade have disappeared. To do nothing to support these workers risks leaving hundreds of thousands of them behind as the economy recovers (Carnavale, Smith, \& Strohl, 2010).

Demand for workers with college educations will outpace supply to the tune of 300,000 per year. By 2018, the post-secondary system will have produced 3 million fewer college graduates than demanded by the labor market (Carnavale, Smith, \& Strohl, 2010). The emphasis on post-secondary preparation for new hires means that workers will tend to be attached to an occupation and not on industry. The day when people left high school to go to work in local business and then work their way up is disappearing. Starting out, straight from high school, to get on-the-job training and then advancing to upper management positions is no longer an option. People do not go to work in industries any more. They get educated or trained, go to work in occupations, and progress in an occupational hierarchy (Carnavale, Smith, \& Strohl, 2010).

\section{SUMMARY}

For educators, the good news is that the demand for education and training is on the rise. Jobs, regardless of occupation, are requiring more and more post-secondary preparation, regardless of industry. Computer technology is transforming the American economy. Just like electricity in the industrial age, the computer is used across industries and in the larger society to increase productivity (Carnavale, Smith, \& Strohl, 2010). Computer-based technology adds new kinds of value to goods and services that were simply impossible in previous economic eras. Information technology provides convenience because its accessibility is not limited by time and space. Consumers can order goods or services from anywhere in the world or bank remotely at any time of day or night. Likewise, e-Learning 
provides the flexibility to use computers to learn anywhere and anytime. Interestingly, very little is currently known about technology skills and how they are learned and applied across business-related occupations. The future success of individuals, as well as the country as a whole, will, in large part, be determined by the success of online learning and how using technology translates into meeting the needs of businesses for an adequately trained and educated workforce.

\section{AUTHOR INFORMATION}

Paul J. Carruth, Ph.D., CPA is a Professor of Accounting at Southeastern Louisiana University. He can be reached at Southeastern Louisiana University, School of Business, SLU Box 10468, Hammond, LA. He has written extensively about educational issues. E-mail: pcarruth@selu.edu (Corresponding author)

Ann K. Carruth, DNS, RN is a Professor of Nursing and Dean at Southeastern Louisiana University. She can be reached at Southeastern Louisiana University, School of Nursing \& Health Sciences, SLU Box 10781, Hammond, LA 70402. She too has written extensively about educational issues. E-mail: acarruth@ selu.edu

\section{REFERENCES}

1. Bower, B. (2001). Distance Education: Facing the faculty challenge. Online Journal of Distance Learning Administration, 4(2). Available at http://www.westga.edu/ distance/ojdla/summer42/bower42.html

2. Bartsch, K.J. (2009). The employment projections for 2008-18, Monthly Labor Review Online, 132 (11).

3. Carnevale, AP, Smith, N. and Strohl, J. (2010).Projecting Jobs and Education Requirements Through 2018 [online] (Washington, D.C.: Georgetown University Center on Education and the Workforce, June 2010). Available at: http://www9.georgetown.edu/grad/gppi/hpi/cew/pdfs/FullRe-port.pdf

4. Dougherty, K.J. and Natow, R.S., (2009).The Demise of Higher Education Funding Systems in Three States" [online], Community College Research Center Working Paper No. 17, Teachers College, Columbia University, New York, N.Y. Available at: http://www.eric.ed.gov/PDFS/ED505706.pdf

5. Garner, CA.(2004). Offshoring in the Service Sector: Economic Impact and Policy Issues. Federal Reserve Bank of Kansas City, Economic Review, 3rd.Quarter, 5-37.

6. Harry J. Holzer and Robert I. Lerman, (2009). The Future of Middle-Skill Jobs (Washington, DC: Brookings Institution), http://www.brookings.edu/ /media/Files/rc/papers/2009/02_middle_skill_jobs_holzer/02_middle_skill_job s_holzer.pdf

7. Kenny, A. (2002), Online learning: enhancing nursing education? Journal of Advanced Nursing, 38 (2): 127-135.

8. Kirsch, I., Braun, H. and Yamamoto, K. (2007). America's Perfect Storm: Three Forces Shaping America's Future (Princeton, NJ: Policy Evaluation and Research Center, Policy Information Center, Educational Testing Service), http://www.ets.org/Media/Research/pdf/PICSTORM.pdf

9. Kirsch, I., Jungeblut, A., Jenkins, L., and Kolstad, A. (2003). Adult Literacy in America: A First Look at Results of the National Adult Literacy Survey, U.S. Department of Education.

10. Lacey, A., \& Wright, B. (2009). Occupational employment projections to 2018. Monthly Labor Review Online, 132 (11).

11. Lewin, T. (2011). M.I.T. expands its free online courses. The New York Times, December 19th, 2011.

12. Means, B., Toyama, Y., Murphy, R., Bakia, M., Jones, K. (2009), Evaluation of Evidence-Based Practices in Online Learning: A Meta-Analysis and Review of Online Learning Studies, http://www.ed.gov/rschstat/eval/tech/evidence-based-practices/finalreport.pdf

13. Metrejean, E. \& Noland, T. (2011). An analysis of CPA Firm Recruiters' Perceptions of online masters of accounting degrees. Journal of Education for Business. 86, 25-30.

14. Organisation for Economic Cooperation and Development and Statistics Canada,. (2005). Learning a Living: First Results of the Adult Literacy and Life Skills Survey, Paris.

15. Sparks, E. \& Waits, M.J. (March 2011). Degrees for what jobs? Raising expectations for universities and colleges in a global economy. NGA Best Practices, p. 1-48.

16. U.S..Bureau.of.Labor.Statistics, (2005). Employment.Outlook:.2004-14, Monthly Labor Review. 
17. U.S. Department of Labor, Occupational Projections and Training Data: 2006-07 Edition, (Washington, D.C.: U.S. Government Printing Office, 2006).

18. Wolanin, T.R. (2003). Reauthorizing the Higher Education Act: Issues and Options. Institute for Higher Education Policy. Available from the World Wide Web at http://ihep.org/publications.html 